\title{
TIRE CRUMB RUBBER EFFECT ON HOT BITUMINOUS MIXTURES FATIGUE-CRACKING BEHAVIOUR
}

\author{
Fernando MORENO-NAVARRO, Maria Carmen RUBIO-GÁMEZ, \\ Ana JIMÉNEZ DEL BARCO-CARRIÓN \\ Construction Engineering Laboratory, University of Granada, 18071 Granada, Spain
}

Received 07 Feb 2013; accepted 14 Mar 2013

\begin{abstract}
The use of tire crumb rubber in road engineering as a modifier of bituminous mixes constitutes one of the revalorization techniques for this waste. The main objective of this research consists of analysing the possible fatigue cracking improvements in the performance of bituminous mixtures containing crumb rubber in comparison to bituminous mixtures manufactured with conventional bitumen and bitumen modified with SBS polymers. For this purpose, four different types of mixes with the same mineral skeleton but different bitumens were studied. The test used to evaluate their behaviour was the UGR-FACT with an additional system for taking pictures, which allows controlling the propagation of the cracks at every moment. The results show that the addition of crumb rubber retards the appearance of cracks; however, once it begins, the damage propagation is faster. Therefore, the fatigue cracking life of mixes with crumb rubber seems considerably longer than the fatigue cracking life of those with conventional bitumens. Moreover, in the mixes with crumb rubber added by the dry process, cracks are thinner and less ramified than in the other ones.
\end{abstract}

Keywords: crumb rubber, fatigue cracking, asphalt mixes, laboratory test.

\section{Introduction}

In the last years, waste valorisation has become an important issue due to the policies of environmental sustainability. Civil engineering has an important effect on the consumption of natural resources; thus, the application of new techniques is crucial to contribute with these policies. In this sense, the reuse of scrap tires as a modifier of the mechanical properties of materials has become increasingly useful in recent years. Scrap tires are one of the main wastes all over the world, and its reuse in the manufacture of concrete (Grinys et al. 2012) or bituminous mixtures (Huang et al. 2007; Santucci 2009) supposes an effective alternative to reduce their impact on the environment (it can enlarge the service life of these materials and reduce the disposal of a waste in the landfills).

Therefore, the use of crumb rubber from scrap tires in road engineering as a modifier of bituminous mixes is becoming a common practice. When crumb rubber interacts with the bitumen, it modifies the rheological properties of the resulting mix (lower susceptibility to temperature and better elastic performance) and increases its viscosity (Ruiz 2010). The processes used to incorporate crumb rubber in asphalt paving mixes are the Wet process (in which the crumb rubber is directly added to the bitumen, prior to mixing it with the aggregates; then it is added to the mix as modified binder) and the Dry process (in which the crumb rubber is added to the aggregate as another ingredient in the mix, prior to the addition of the bitumen, and the bitumen is then modified when it comes in contact with the rubber).

Recent studies have demonstrated that the reuse of crumb rubber in hot bituminous mixtures, independently of the process used, could lead to improve its bearing capacity (Navarro, Gámez 2012), its stability and its resistance to plastic deformation (Moreno et al. 2011, 2013). These studies show that the performance of crumbrubber-modified (CRM) bituminous mixes could be similar to the mixes manufactured with polymer modified bitumen (Radziszewski et al. 2012; Biro, Fazekas 2012; Zeiada et al. 2012).

Other studies have shown that the long term performance in hot bituminous mixtures modified with crumb rubber improve in comparison to bituminous mixtures manufactured with conventional bitumen (Sibal et al. 2000). In terms of fatigue cracking behaviour, Mamlouk and Mobasher (2011) showed that asphalt rubber mixtures has a higher fracture toughness and consequently larger resistance to fatigue cracking than conventional asphalt mixtures at low temperatures $\left(-7^{\circ} \mathrm{C},-1^{\circ} \mathrm{C}\right)$. The same conclusions were obtained by other researchers at medium $\left(21^{\circ} \mathrm{C}, 24^{\circ} \mathrm{C}\right)$ and high temperatures $\left(37.8^{\circ} \mathrm{C}\right)$ (Mull et al. 2005; Abojaradeh et al. 2010).

Corresponding author: Fernando Moreno-Navarro

E-mail:fmoreno@ugr.es 
Based on these results, it can be said that the reuse of crumb rubber in the manufacture of bituminous mixtures could reduce the fatigue cracking in the surface layer, being a possible solution to diminish one of the most common distresses in pavements. Nevertheless, all these studies only compare the fatigue cracking behaviour of CRM bituminous mixtures with conventional bitumen mixes, but traditionally the binders used to combat asphalt cracking in the mixtures placed on surface layers are polymer (SBS, EVA, etc.) modified bitumen (Moghaddam et al. 2011). Therefore, in order to know the real value of CRM mixtures as a possible sustainable solution against fatigue cracking, it is necessary to compare its mechanical behaviour with bituminous mixtures manufactured with polymer modified bitumen mixtures.

The research presented in this paper analyses the fatigue cracking behaviour of CRM asphalt mixtures with conventional and modified bitumen. For this purpose, a study was conducted on four mixes of similar characteristics, but varying the type of bitumen used (conventional bitumen, SBS polymer modified bitumen, high-viscosity rubber modified bitumen added by the wet process, and conventional bitumen modified with $1.5 \%$ of crumb rubber added by the dry process). The experiments were performed with the University of Granada - Fatigue Asphalt Cracking Test (UGR-FACT).

\section{Materials}

This study analysed the behaviour of four BBTM bituminous mixtures for road surface courses (UNE-EN 13108-2) with very similar characteristics. This type of mixture is gap-graded, with a maximum aggregate size of $12 \mathrm{~mm}$ from which the $2-4 \mathrm{~mm}$ fraction is eliminated (Fig. 1). It is generally spread in a thin layer $(2-3.5 \mathrm{~cm})$, and used for the surface rehabilitation of deteriorated pavements as well as for the construction of new roads. All the mixtures were designed with the same mineral skeleton, but varying the type of bitumen (conventional bitumen "B50/70"; polymer SBS modified bitumen "BM3c"; high-viscosity rubber modified bitumen "HVRMB"; and conventional bitumen modified with $1.5 \%$ of crumb rubber over the total weight of the mix using the dry process "B50/70 1.5\% CR"). Table 1 shows the properties of the four mixtures studied.

The aggregates used for the coarse fraction was ophite, and limestone was used for the fine one. The characteristics of these types of aggregates are shown in Table 2.

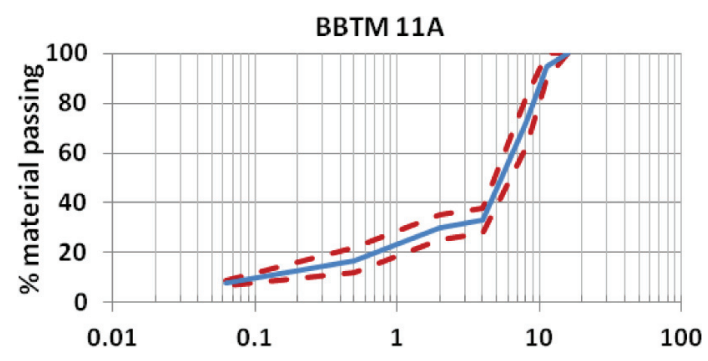

Fig. 1. Aggregate grain-size curve
Table 1. Bituminous mixtures properties

\begin{tabular}{lcccc}
\hline Test & $\begin{array}{r}\text { BBTM } \\
\text { B50/70 }\end{array}$ & $\begin{array}{c}\text { BBTM } \\
\text { BM3c }\end{array}$ & $\begin{array}{c}\text { BBTM } \\
\text { HVRMB }\end{array}$ & $\begin{array}{c}\text { BBTM } \\
\text { B50/70 } \\
1.5 \% \text { CR }\end{array}$ \\
\hline $\begin{array}{l}\text { Bitumen } \\
\text { Content, \% }\end{array}$ & 4.9 & 4.75 & 4.75 & 5 \\
\hline $\begin{array}{l}\text { Bulk Density, } \\
\text { kg/m } 3\end{array}$ & & & & \\
(UNE-EN & 2493 & 2483 & 2506 & 2669 \\
$12697-6$ 2012) & & & & \\
\hline $\begin{array}{l}\text { Voids in mix, \% } \\
\text { (UNE-EN }\end{array}$ & 4.1 & 7.1 & 4.0 & 4.0 \\
$\begin{array}{l}\text { 12697-8 2003) } \\
\text { Voids aggregate } \\
\text { (UNE-EN }\end{array}$ & & & & \\
$12697-8$ 2003) & 16.1 & 19.8 & 15.9 & 18 \\
\hline
\end{tabular}

Table 2. Aggregate characteristics

\begin{tabular}{lc}
\hline \multicolumn{1}{c}{ Ophite coarse aggregate } \\
\hline $\begin{array}{l}\text { Percentage of fractured face (UNE-EN 933-5 } \\
\text { 1999) }\end{array}$ & 100 \\
\hline Flakiness index (UNE-EN 933-3 2012) & 20 \\
\hline $\begin{array}{l}\text { Resistance to fragmentation (UNE-EN 1097-2 } \\
\text { 2010) }\end{array}$ & 11 \\
\hline $\begin{array}{l}\text { Resistance to polishing (UNE 12593, annex D } \\
\text { 2007) }\end{array}$ & 52 \\
\hline $\begin{array}{l}\text { Relative density, g/cm }{ }^{3} \text { (UNE-EN 1097-6 } \\
\text { 2001) }\end{array}$ & 0.04 \\
\hline $\begin{array}{l}\left.\text { Apparent Density, (g/cm }{ }^{3}\right) \text { (UNE-EN 1097-6 } \\
\text { 2001) }\end{array}$ & 3.14 \\
\hline \multicolumn{1}{c}{ Limestone fine aggregate } \\
\hline Sand equivalent (UNE-EN 933-8 2012) \\
\hline $\begin{array}{l}\text { Apparent Density, (g/cm }{ }^{3} \text { ) (UNE-EN 1097-6 } \\
\text { 2001) }\end{array}$ \\
\hline
\end{tabular}

The filler selected for the mixes was cement whose apparent density is $0.7 \mathrm{~g} / \mathrm{cm}^{3}$ (by the procedure of UNE-EN 1097-6 2001).

The characteristics of the different types of bitumen are listed in Table 3. The crumb rubber used in the dryprocess CRM mixture had a particle size of $0.6 \mathrm{~mm}$. The rest of its properties are shown in Table 4.

Table 3. Bitumen characteristics

\begin{tabular}{lccc}
\hline & B 50/70 & BM3c & HVRMB \\
\hline $\begin{array}{l}\text { Penetration at 25 }{ }^{\circ} \mathrm{C} \\
\text { (UNE-EN 1426 2007) }\end{array}$ & $68 \mathrm{~mm} / 10$ & 54 & 54 \\
\hline $\begin{array}{l}\text { Softening point } \\
\text { (UNE-EN 1427 2007) }\end{array}$ & $48.1^{\circ} \mathrm{C}$ & $68.1^{\circ} \mathrm{C}$ & $69.5{ }^{\circ} \mathrm{C}$ \\
\hline $\begin{array}{l}\text { Fragility temperature } \\
\text { (Fraass method) } \\
\text { (UNE-EN 12593 2007) }\end{array}$ & $-12{ }^{\circ} \mathrm{C}$ & $-17{ }^{\circ} \mathrm{C}$ & $-15^{\circ} \mathrm{C}$ \\
\hline $\begin{array}{l}\text { Elastic recovery at 25 }{ }^{\circ} \mathrm{C} \\
\text { (NLT 329 1991) }\end{array}$ & - & $73 \%$ & $80 \%$ \\
\hline
\end{tabular}


Table 4. Properties of the crumb rubber added to the dry-process CRM mixes

\begin{tabular}{lcc}
\hline Properties & \multicolumn{2}{c}{1.15} \\
\hline Density $\left(\mathrm{g} / \mathrm{cm}^{3}\right)$ & \multicolumn{2}{c}{ Black } \\
\hline Color & \multicolumn{2}{c}{ Irregular } \\
\hline Particle morphology & \multicolumn{2}{c}{$<0.75$} \\
\hline Moisture content $(\%)$ & \multicolumn{2}{c}{$<0.5$} \\
\hline Textile content $(\%)$ & \multicolumn{2}{c}{$<0.1$} \\
\hline Metal content $(\%)$ & \multicolumn{2}{c}{$0.600-0.063$} \\
\hline Particle Size $(\mathrm{mm})$ & Min. $(\%)$ & Max. $(\%)$ \\
\hline Composition & 7.5 & 17.5 \\
\hline Cetonic extract & 21.0 & 42.0 \\
\hline Natural rubber (NR) & 50.0 & 55.0 \\
\hline Polymers $(\mathrm{NR} / \mathrm{SBR})$ & - & 5.0 \\
\hline Sulfur & 20.0 & 38.0 \\
\hline Carbon black & - & 18.5 \\
\hline Ash & &
\end{tabular}

\section{Methodology}

In order to analyse the fatigue cracking behaviour of the mixtures, the UGR-FACT was used (Moreno, Rubio 2013). The test device provides valuable fatigue-cracking data by initiating and propagating a controlled cracking process in a representative volume of the bituminous mix in which the cracking occurs. By analysing the energy dissipated during the process, this test method is able to accurately evaluate the damage produced as well as the mechanical performance of the mix. The device is composed of a base with two sliding supports (Fig. 2a) placed over rails that allow the supports to change position without any pitching or residual movement (which could lead to errors in deformation measurements). Although the initial distance between supports (D) is variable, it was fixed as $0 \mathrm{~mm}$ for the tests carried out in this research (in order to simulate a crack which is coming from the lower layer). On the surface of the supports, there are two support plates to which the test specimen is
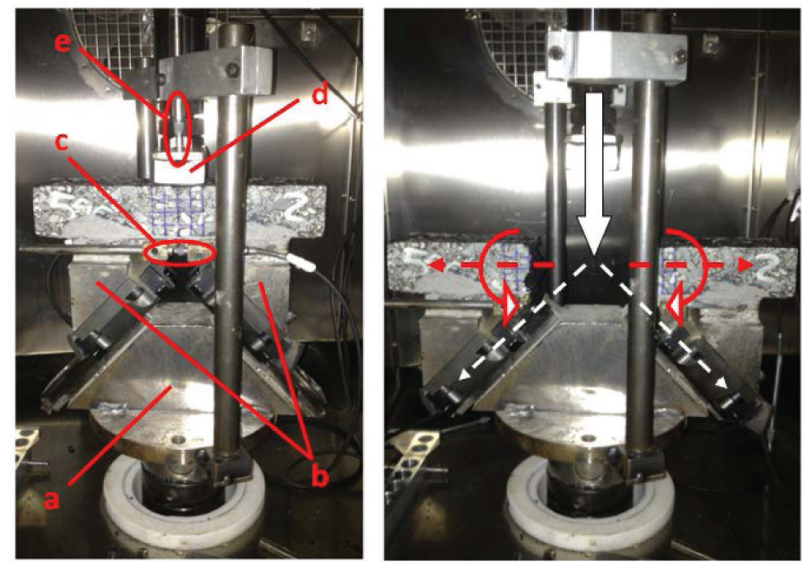

Fig. 2. UGR- FACT test device attached with epoxy resin. The sliding supports also have two auxiliary elements (one on each side, Fig. 2b) where the horizontal deformation gauges (LVDT) are located (Fig. 2c). The head of the load application (Fig. 2d) is independent of the body of the device, and it is composed of a piece of steel with a flat surface for the vertical deformation gauges (Fig. 2e).

The test is performed at a controlled temperature inside a climate chamber by applying stress-controlled, vertical cyclic loading in versed sine. The test ends when the macro-crack propagates throughout the entire specimen (represented by failure cycle, $N_{f}$ ). This causes its failure by fracturing it into two sections. During each loading cycle, besides the load applied, the device records horizontal and vertical deformations on both sides of the test specimen (to obtain the mean deformation value of the representative volume studied). These deformations occur in the area near the stressed zone where the crack will develop and spread.

Based on the values recorded, it is possible to determine the energy dissipated by the material in the volume studied, which leads to a more precise evaluation of the evolution of the damage that take place during the cracking process (controlling its randomness and three-dimensional distribution). Nevertheless, any damaged material is also characterized by a corresponding change in dissipated energy (Ghuzlan 2001). Because of this, it is necessary to use the ratio of dissipated energy change (RDEC, Eqn (1)) to analyse the evolution and real quantification of crack damage in the mix (Carpenter, Jansen 1997; Ghuzlan, Carpenter 2000; Shen, Carpenter 2007).

$$
R D E C=\frac{\omega_{n+1}-\omega_{n}}{\omega_{n}},
$$

where: $\omega_{n}$ is the energy dissipation produced in the loading cycle $n\left(\right.$ in $\left.\mathrm{J} / \mathrm{m}^{3}\right)$; and $\omega_{n+1}$ is the energy dissipation in the loading cycle $n+1$ (in $\left.\mathrm{J} / \mathrm{m}^{3}\right)$.

The RDEC provides a precise calculation of the damage to the mix from one cycle to another (Shen, Carpenter 2007). Therefore, the cumulative RDEC is an accurate way of quantifying the evolution of the cracking process that is generated during the test. As a result, it is possible to calculate a mean damage parameter (MDP, Eqn (2)) for the cracking process in each mix and for each condition. The higher the value of the mean damage parameter, the lower the resistance to fatigue cracking:

$$
M D P=\frac{\sum_{i=1}^{N_{f}} R D E C_{i}}{N_{f}},
$$

where: $R D E C_{i}$ is the ratio of dissipated energy change in each cycle; and $N_{f}$ is the number of cycles in the test (cycle of failure).

The fatigue cracking behaviour of the different mixtures was evaluated by varying the load amplitude 
Table 5. Testing protocol with the UGR-FACT

\begin{tabular}{lcccc}
\hline \multirow{2}{*}{ Mix } & $\begin{array}{c}\text { Load } \\
\text { Amplitude } \\
(\mathrm{kN})\end{array}$ & $\begin{array}{c}\text { Frequency } \\
(\mathrm{Hz})\end{array}$ & $\begin{array}{c}\text { Test Temp. } \\
\left({ }^{\circ} \mathrm{C}\right)\end{array}$ & $\begin{array}{c}\mathrm{D} \\
(\mathrm{mm})\end{array}$ \\
\hline \multirow{2}{*}{$\begin{array}{c}0.5 \\
\text { BMTM }\end{array}$} & 0.75 & 5 & 20 & 0 \\
\cline { 2 - 5 } & 1.0 & 5 & 20 & 0 \\
\hline BBTM & 0.5 & 5 & 20 & 0 \\
\cline { 2 - 5 } B50/70 & 0.75 & 5 & 20 & 0 \\
\cline { 2 - 5 } & 1.0 & 5 & 20 & 0 \\
\hline BBTM & 0.5 & 5 & 20 & 0 \\
\cline { 2 - 5 } BMAVC & 0.75 & 5 & 20 & 0 \\
\hline & 1.0 & 5 & 20 & 0 \\
\hline BBTM & 0.5 & 5 & 20 & 0 \\
B50/70 + & 0.75 & 5 & 20 & 0 \\
\cline { 2 - 5 } $1.5 \%$ CR & 1.0 & 5 & 20 & 0 \\
\hline
\end{tabular}

of the test $(1.0 \mathrm{kN}, 0.75 \mathrm{kN}$, and $0.5 \mathrm{kN})$. The frequency was fixed at $5 \mathrm{~Hz}$, and the test temperature selected was $20{ }^{\circ} \mathrm{C}$. Table 5 shows the different tests carried out with the UGR-FACT.

The specimens manufactured for each test were made from the same mass in order to guarantee their homogeneity. The mass was divided into different parts, which were then compacted in the laboratory with a roller segment compactor (as specified in Standard UNE EN 12697-33 2006) to obtain prism-shaped specimens $(408 \times 256 \times 40 \mathrm{~mm})$. The dimensions of the final test specimens $(200 \times 60 \times 40 \mathrm{~mm})$ were obtained by sawing these prism-shaped specimens and previously eliminating their edges to avoid possible imperfections.

In order to visually analyse the evolution of the damage in the material, pictures were taken with a highdefinition camera during the test. In addition, the area of fracture of each picture was measured using a digital treatment. In that way, the damage evolution could be graphically quantified in $\mathrm{mm}^{2}$.

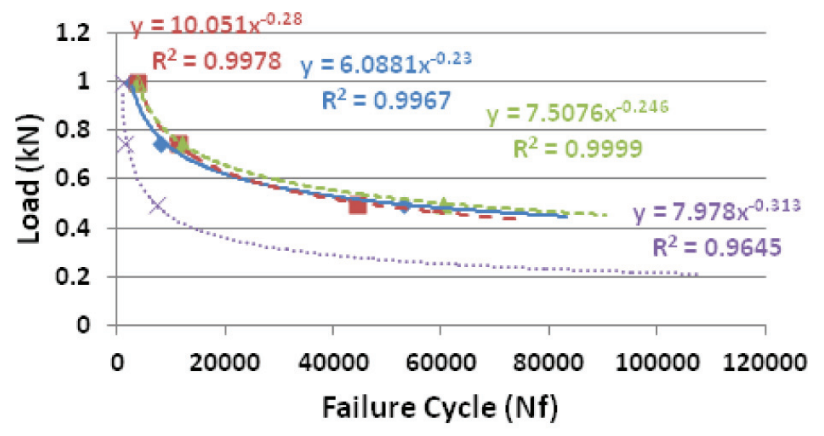

- BM3c $\square$ HVRMB $\triangle \mathrm{B} 50 / 70+1.5 \% C R \times B 50 / 70$

Fig. 3. Fatigue life of the mixes tested

\section{Results and discussion}

The results obtained from the regression analysis of the level of load applied and the cycle of failure of each mixture are exposed in Figure 3. It can be observed that the fatigue life of all the modified bitumens is very similar, independently of the modification applied to the bitumen (SBS polymer, high-viscosity rubber or $1.5 \%$ of crumb rubber added by the dry process). The mix manufactured with conventional bitumen shows a shorter fatigue life. This fact reflects that the fatigue behaviour of conventional bitumen is worse than the behaviour of the modified ones. These results demonstrate that the use of crumb rubber in the production of bituminous mixtures can enlarge their fatigue life and improve their behaviour in the long term, having a similar behaviour to highperformance mixtures made with SBS polymers.

The dissipated energy values calculated during the tests are displayed in Figure 4. At the beginning of the test, the dissipated energy of the mixture made with modified bitumen with crumb rubber added by the dry process is less than the dissipated energy of the mixtures made with SBS polymer modified bitumen, high-viscosity rubber modified bitumen, and conventional bitumen. Due
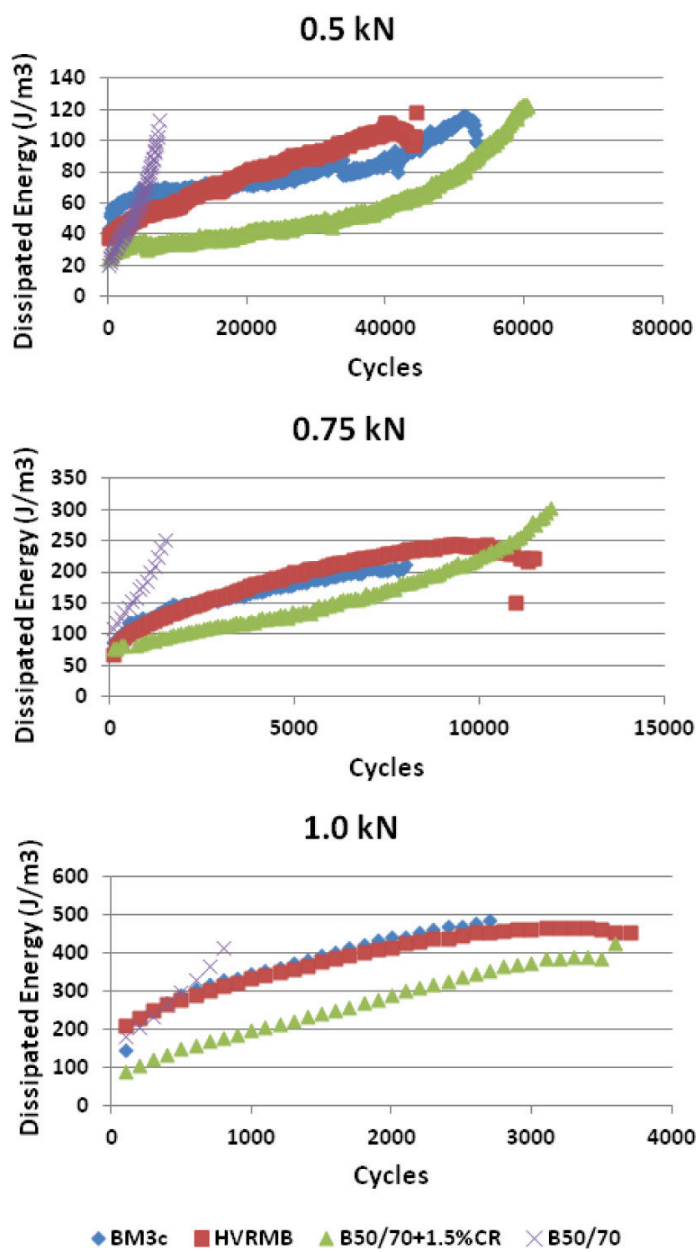

Fig. 4. Dissipated energy of the tested asphalt mixes 


\section{$0.5 \mathrm{kN}$}

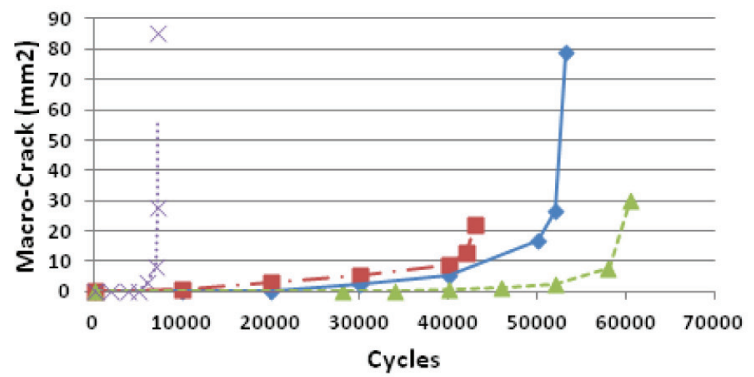

$0.75 \mathrm{kN}$

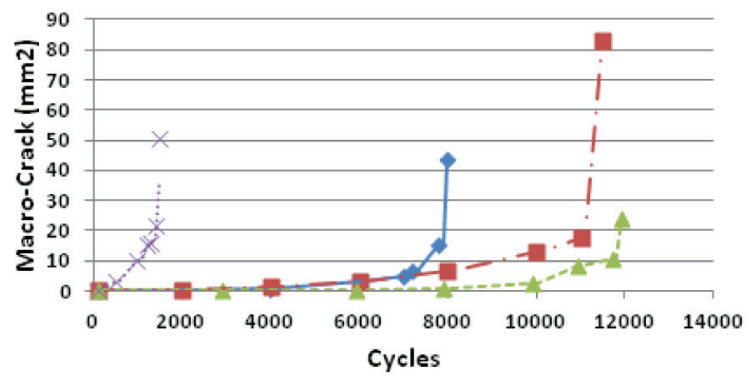

$1.0 \mathrm{kN}$

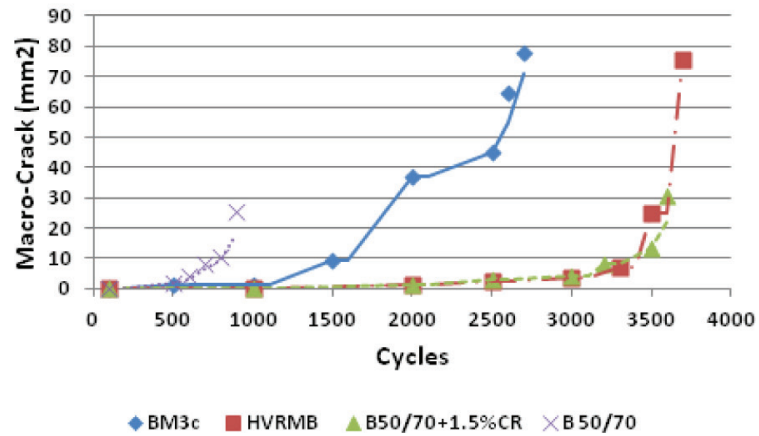

Fig. 5. Macro-crack areas evolution during the tests

to this fact, the cracking damage of this material is more reduce than in the rest of them, and consequently a macro-crack will appear later independently of the type of load applied. Figure 5 shows this behaviour displaying the evolution of the area of the macro-cracks (measured with the pictures taken during the tests) in each cycle.

Despite this fact, due to the influence of the type of bitumen in stiffness modulus (DelRio-Prat et al. 2011), and as some researchers have exposed (Navarro, Gámez 2012; Moreno et al. 2013), bituminous mixtures made with modified bitumen with crumb rubber added by the dry process are stiffer than mixtures made with other modified bitumens. This aspect helps to delay the development of plastic deformations in them (and consequently to resist cracking), but once the macro-crack has appeared, it spreads quicker through the specimen than in other materials (due to a more fragile response of it). Therefore, at the last phase of the test, the energy dissipated in each loading cycle by the mix with crumb rubber added by the dry process increases until it exceeds the energy dissipated by the mixtures made with the other modified bitumens.
On the other hand, from the analysis of Figure 4 the high energy dissipation rate of the mix made with conventional bitumen can be observed, which indicates a fast propagation of the cracking damage and hence its short fatigue life. In addition, this figure shows that the energy dissipated by the mixture with SBS polymer modified bitumen and by the one with high viscosity crumb rubber modified bitumen are very similar. This fact implies that the performance of both bitumens in terms of fatigue cracking is comparable.

Figure 6 displays the results of the accumulated RDEC. It shows that the propagation of the cracking damage is faster for the mixture made with conventional bitumen than for the other mixes made with modified bitumens. At the beginning, the spreading of the damage in the modified bitumen with crumb rubber by the dry process is lower, but at the last phase it surpasses the others. Moreover, the damage propagation of the SBS polymer modified bitumen and the high viscosity crumb rubber modified bitumen is equivalent.

In this sense, Figure 7 shows the pictures of the specimens at the failure loading cycle, having been tested under the same conditions and level of load. The fact that

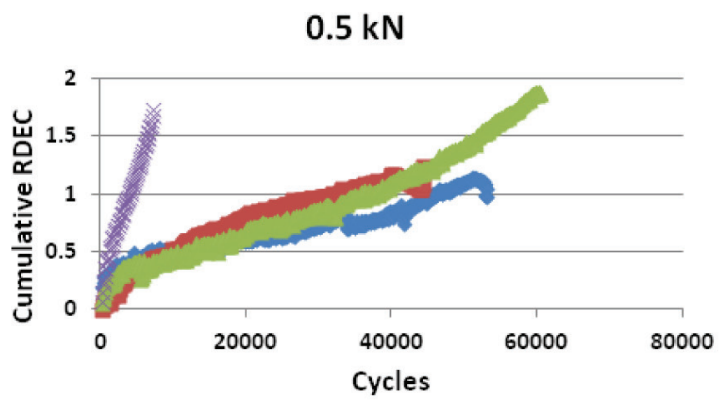

$0.75 \mathrm{kN}$

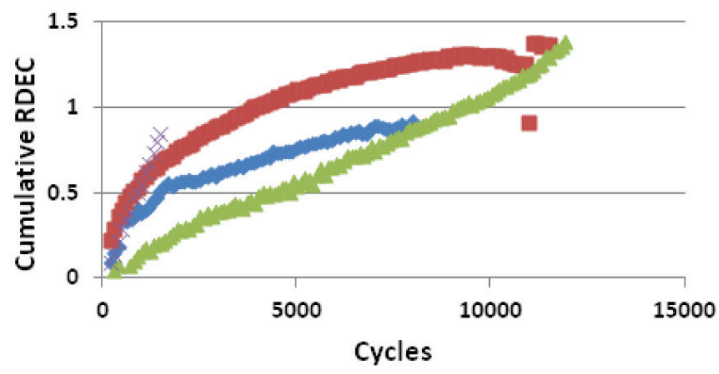

$1.0 \mathrm{kN}$

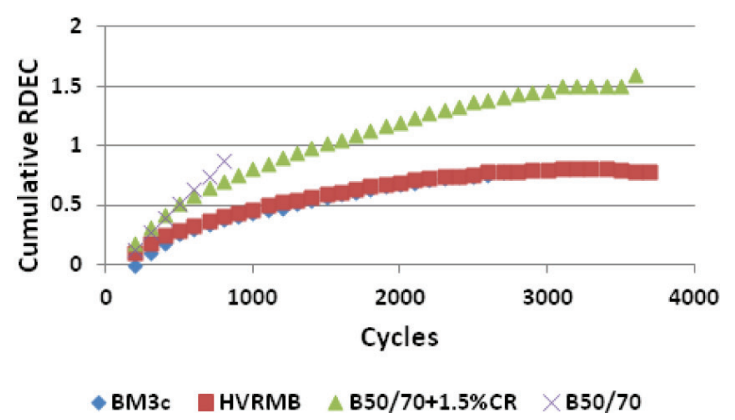

Fig. 6. Cumulative RDEC of the mixes tested 

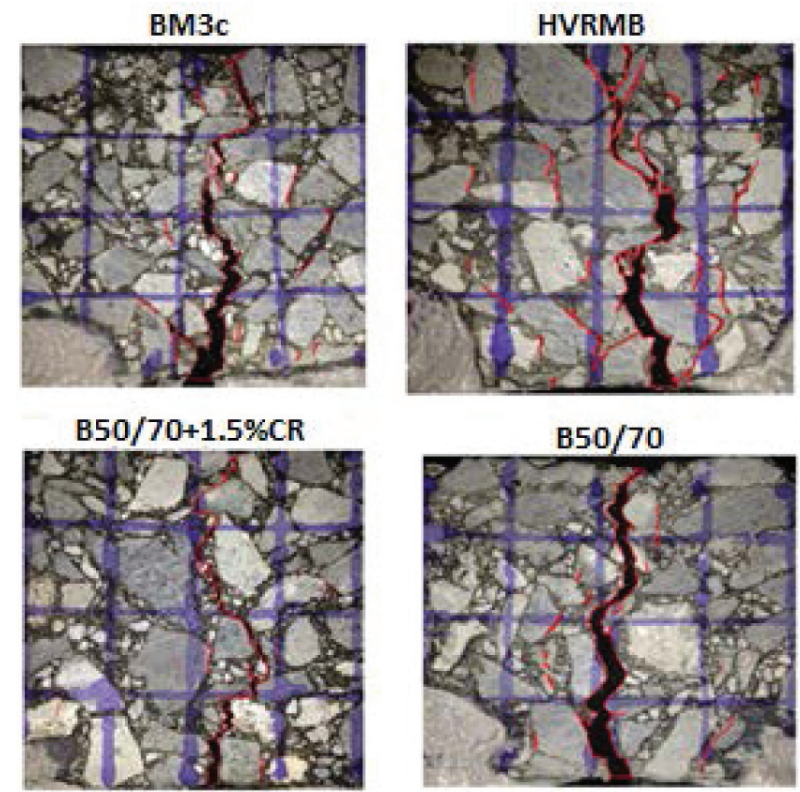

Fig. 7. Pictures of the failure cycle of the mixes tested

the picture of the mix manufactured with modified bitumen with crumb rubber by the dry process shows a clean, thin and without ramifications cracking process confirms that the material is stiff and the crack propagation is fast. On the other hand, the cracking of the mixes made with SBS polymer modified bitumen and high viscosity crumb rubber modified bitumen is more ramified and has a failure surface with larger thickness. This type of failure is associated with materials that have a more plastic cracking, which delays the process once it has begun. In addition, these materials are able to have several small cracks that, at the end, create a main larger macro-crack. Finally, the failure in the mix with conventional bitumen has a cleaner crack than in the mix with modified bitumens; however, it has a larger thickness than the crack of the bitumen modified with crumb rubber by the dry process, which means that it is a faster and sharper breaking.

The mean damage parameter was calculated from the accumulated RDEC values for each level of load for the mixes tested (Fig. 8). The bituminous mixtures manufactured with modified bitumens have a lower character-

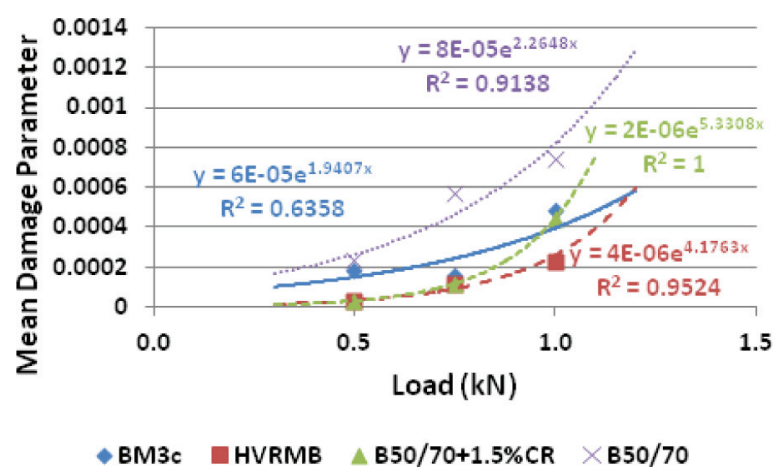

Fig. 8. Mean damage parameter of the mixes tested
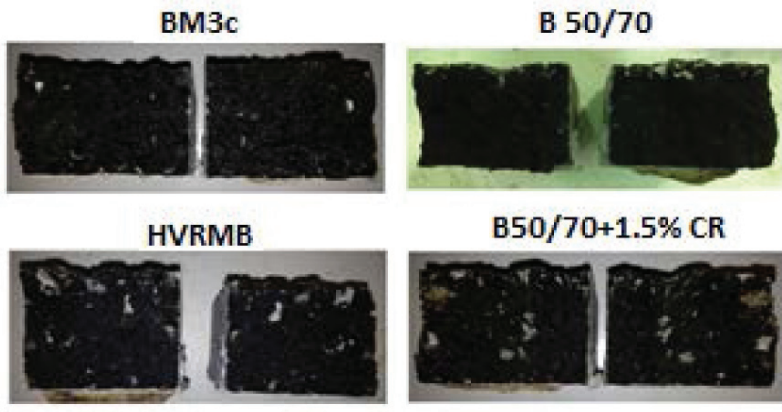

B50/70+1.5\% CR

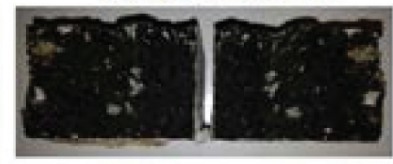

Fig. 9. Pictures of the cracking surface of the mixes tested

istic parameter than the mix of conventional bitumen, independently of the type of load. Respects to the modified bitumens, the ones with crumb rubber have a better fatigue response than the bitumen modified with SBS polymers. Nevertheless, for higher levels of load, due to its larger stiffness, the damage of the mix with bitumen modified with crumb rubber added by the dry process increases until being similar to the damage of the mix with SBS polymer modified bitumen.

Finally, Figure 9 shows pictures of the BBTM mixes with the different bitumens after having been tested. In the conventional bitumen and SBS polymer modified bitumen mixes the crack spreads through the bitumen without breaking the aggregates. In contrast, in the mixes with bitumen modified with crumb rubber, despite being the same aggregates, they are cracked. This fact could be due to an improvement of the adherence between the aggregates and the bitumen thanks to the addition of crumb rubber. For this reason, the crack would appear later, because it has to spread through the aggregates, instead of surrounding them.

\section{Conclusions}

This paper studies the effect of tire crumb rubber on the fatigue-cracking behaviour of asphalt mixes. Four BBTM asphalt mixes with the same mineral skeleton, but different types of bitumen (B 50/70, BM3c, HVRMB, B $50 / 70+1.5 \% \mathrm{CR}$ ) were studied by applying the UGRFACT test protocol. Based on the findings of this study, the following conclusions can be drawn:

- The addition of crumb rubber to asphalt mixes could retard the appearance of fatigue cracking process during its service life, independently of the application process used.

- There are not significant differences between the fatigue cracking life of crumb rubber modified asphalt mixes using the dry process and the wet process.

- The results obtained showed that the fatigue cracking behaviour of CRM mixes is quite similar to the fatigue cracking behaviour of polymer modified mixes. The fatigue cracking life is considerably longer than the fatigue cracking life of conventional bitumens. Furthermore, under the same level of 
load, the cracking damage associated to the mixes manufactured with modified binder is less than in conventional bitumens mixtures.

- The response of the crumb rubber modified bitumen added by the wet process is very similar to the SBS polymer modified bitumen. Therefore, crumb rubber could be an alternative to SBS polymers as an anticracking method.

- The addition of crumb rubber by the dry process induces a more elastic behaviour in asphalt mixes, and retards the crack initiation process. Nevertheless, once the macro-crack is appeared, the damage is propagated faster.

- The addition of crumb rubber by the dry process produces thinner and cleaner cracks, which allows an easier and more effective treatment of this pathology.

- The addition of crumb rubber seems to improve the adherence between the aggregates and the bitumen. Therefore, cracks appear later, due to they have to break the stone instead of surrounding it.

These results show that the CRM mixes could be an alternative to polymer modified bitumens in order to reduce the impact caused by the fatigue cracking in asphalt pavements and to give a new value to a waste which constitute an environmental advantage.

\section{References}

Abojaradeh, M.; Jrew, B.; Ghragheer, F.; Kaloush, K. E.; Abojaradeh, D. 2010. Cracking characteristic of asphalt rubber mixtures, Jordan Journal of Civil Engineering 4: 205-210.

Biro, S.; Fazekas, B. 2012. Asphalt rubber versus other polymer modified bitumens, in Proc. of the $5^{\text {th }}$ Asphalt Rubber Conference, 23-26 October 2012, Munich, Germany, 351-366.

Carpenter, S. H.; Jansen, M. 1997. Fatigue behavior under new aircraft loading conditions, in Proc. of the Aircraft Pavement Technology in the Midst of Change (ASCE), 17-20 August 1997, Seattle, Washington, VA, 259-271.

DelRio-Prat, M.; Sanchez-Alonso, E.; Vega-Zamanillo, A.; Castro-Fresno, D. 2011. Effect of aggregate shape and size and surfactants on the resilient modulus of bituminous mixes, Canadian Journal of Civil Engineering 38(8): 893-899. http://dx.doi.org/10.1139/111-057

Ghuzlan, K.; Carpenter, S. H. 2000. An energy-derived/damage based failure criteria for fatigue testing, Transportation Research Record: Journal of the Transportation Research Board 1723: 141-149. http://dx.doi.org/10.3141/1723-18

Ghuzlan, K. 2001. Fatigue damage analysis in asphalt concrete mixtures based upon dissipated energy concepts: $\mathrm{PhD}$ thesis. University of Illinois at Urbana-Champaign, Urbana, IL.

Grinys, A.; Sivilevicius, H.; Dauksys, M. 2012. Tyre rubber additive effect on concrete mixture strength, Journal of Civil Engineering and Management 18(3): 393-401. http://dx.doi.org/10.3846/13923730.2012.693536

Huang, Y.; Bird, R. N.; Heidrich, O. 2007. A review of the use of recycled solid waste materials in asphalt pavements, Resources, Conservation and Recycling 52: 58-73. http://dx.doi.org/10.1016/j.resconrec.2007.02.002
Mamlouk, M.; Mobasher, B. 2004. Cracking resistance of asphalt rubber mix versus hot-mix asphalt, Road Materials and Pavement Design 5(4): 435-451.

http://dx.doi.org/10.3166/rmpd.5.435-451

Moghaddam, T. B.; Karim, M. R.; Abdelaziz, M. 2011. A review on fatigue cracking and rutting performace of asphalt mixes, Scientific Research and Essays 6: 670-682.

Moreno, F.; Rubio, M. C.; Martínez-Echeverría, M. J. 2011. Analysis of digestion time and the crumb rubber percentage in dry-process crumb rubber modified hot bituminous mixes, Construction and Building Materials 25: 2323-2334.

http://dx.doi.org/10.1016/j.conbuildmat.2010.11.029

Moreno, F.; Rubio, M. C. 2013. Effect of aggregate nature on the fatigue-cracking behavior of asphalt mixes, Materials and Design 47: 61-67. http://dx.doi.org/10.1016/j.matdes.2012.12.048

Moreno, F.; Sol, M.; Martín, J.; Pérez, M.; Rubio, M. C. 2013. The effect of crumb rubber modifier on the resistance of asphalt mixes to plastic deformations, Materials and Design 47: 274-280. http://dx.doi.org/10.1016/j.matdes.2012.12.022

Mull, M. A.; Othman, A.; Mohammad, L. 2005. Fatigue crack propagation analysis of chemically modified crumb rubber asphalt mixtures, Journal of Elastomers and Plastics 37: 73-86. http://dx.doi.org/10.1177/0095244305049898

Navarro, F. M.; Gámez, M. C. 2012. Influence of crumb rubber on the indirect tensile strength and stiffness modulus of hot bituminous mixes, Journal of Materials in Civil Engineering 23(11): 1560-1568.

NLT-329/91. Recuperación elástica por torsión de betunes asfálticos modificados. Ministerio de Obras Públicas y Transportes, 1991. 3 p.

Radziszewski, P.; Pilat, J.; Sarnowski, M.; Król, J.; Krupa, Z. 2012. Asphalt rubber as an alternative of polymer modified bitumen, in Proc. of the $5^{\text {th }}$ Asphalt Rubber Conference, 23-26 October 2012, Munich, Germany.

Ruiz, A. 2010. Mezclas con caucho de neumáticos, in Curso de Mezclas Bituminosas: Dosificación, Fabricación, Puesta en Obra y Control de Calidad, 10 March 2010, Barcelona.

Santucci, L. 2009. Rubber roads: waste tires find a home. Pavement Technology Update. Technology Transfer Program, University of California, Berkley. 1(2), 12 p.

Shen, S.; Carpenter, S. H. 2007. Dissipated energy concepts for HMA performance: fatigue and healing. Center of Excellence for Airport Technology, COE Report No. 29, Technical Report of Research, Federal Aviation Administration, University of Illinois at Urbana-Champaign, Urbana, IL. 240 p.

Sibal, A.; Das, A.; Pandey, B. B. 2000. Flexural fatigue characteristics of asphalt concrete with crumb rubber, International Journal of Pavement Engineering 1(2): 119-132. http://dx.doi.org/10.1080/10298430008901701

UNE-EN 13108-2:2007/AC:2008 Bituminous mixtures. Materials specifications. Part 2: Asphalt concrete for very thin layers. AENOR, Asociación Española de Normalización y Certificación, 2008. 4 p.

UNE-EN 12697-8:2003 Bituminous mixtures. Test methods for hot mix asphalt. Part 8: Determination of void characteristics of bituminous specimens. AENOR, Asociación Española de Normalización y Certificación, 2003. 14 p.

UNE-EN 12697-6:2012 Bituminous mixtures. Test methods for hot mix asphalt. Part 8: Determination of bulk density of bituminous specimens. AENOR, Asociación Española de Normalización y Certificación, 2012. 20 p. 
UNE-EN 933-5:1999 Test of geometrical properties of aggregates. Part 5: Determination of percentage of crushed and broken surfaces in coarse aggregate particles. AENOR, Asociación Española de Normalización y Certificación, 1999. $12 \mathrm{p}$.

UNE-EN 933-3:2012 Test of geometrical properties of aggregates. Part 3: Determination of particle shape. Flakiness index. AENOR, Asociación Española de Normalización y Certificación, 2012. 14 p.

UNE-EN 1097-2:2010 Test for mechanical and physical properties of aggregates. Part 2: Method for the determination of resistance to fragmentation. AENOR, Asociación Española de Normalización y Certificación, 2010. 38 p.

UNE-EN 1097-8:2010 Test for mechanical and physical properties of aggregates. Part 8: Determination of the polished stone value. AENOR, Asociación Española de Normalización y Certificación, 2010. 36 p.

UNE-EN 1097-6:2001 Test for mechanical and physical properties of aggregates. Part 2: Method of particle density and water absorption. AENOR, Asociación Española de Normalización y Certificación, 2001. 34 p.
UNE-EN 933-8:2012 Test of geometrical properties of aggregates. Part 8: Assessment of fines. Sand equivalent test. AENOR, Asociación Española de Normalización y Certificación, 2012. $22 \mathrm{p}$.

UNE-EN 14262007 Bitumen and bituminous binders. Determination of needle penetration. AENOR, Asociación Española de Normalización y Certificación, 2007. 18 p.

UNE-EN 14272007 Bitumen and bituminous binders. Determination of softening point. AENOR, Asociación Española de Normalización y Certificación, 2007. 18 p.

UNE-EN 12593:2007 Bitumen and bituminous binders. Determination of the Fraass breaking point. AENOR, Asociacion Española de Normalización y Certificación, 2007. 20 p.

Zeiada, W.; Underwood, S.; Pourshams, T.; Stempihar, J.; Kaloush, K. 2012. Comparison of conventional, polymer, and rubber asphalt mixtures using viscoelastic continuum damage model, in Proc. of the $5^{\text {th }}$ Asphalt Rubber Conference, 23-26 October 2012, Munich, Germany.

Fernando MORENO-NAVARRO. He is a Lecturer in the Department of Construction Engineering and Engineering Projects and research coordinator of the Construction Engineering Laboratory research group at the University of Granada. His research interests include asphalt mixes, fatigue cracking, reuse of wastes in construction, railway materials, and concrete.

Maria Carmen RUBIO-GÁMEZ. She is a Professor in the Department of Construction Engineering and Engineering Projects and Head of the Construction Engineering Laboratory research group at the University of Granada. Her research interests include asphalt mixes, fatigue cracking, reuse of wastes in construction.

Ana JIMÉNEZ DEL BARCO-CARRIÓN. She is a Researcher in the Construction Engineering Laboratory research group at the University of Granada. Her research interests include asphalt mixes and project management. 